\title{
Impact of Performance Management System on Employee Job Satisfaction in Automobile Companies in Western Province, Sri Lanka
}

\author{
Sandalika, KDM and Jayasekara, $P$
}

\begin{abstract}
Area of the Study

This study attempts to identify the impact of performance management system on employee job satisfaction of executives in the automobile companies in western province, Sri Lanka.

\section{Problem of the Study}

The empirical finding of the impact of performance management system of the employees on their job satisfaction is rare in the Sri Lankan context. Therefore, the problem of the study is developed as: Does performance management system of executives in the automobile companies affect their job satisfaction?
\end{abstract}

\section{Method of the study}

The primary data were collected from 248 respondents in automobile companies in western province by administrating a structured questionnaire, which consisted of 44 statements with 5 points Likert scale. The data analyses included the univariat, and bivariate analyses method conducted using SPSS (version 16.0).

\section{Findings of the Study}

The major finding of the study is that there is a strong positive impact of performance management system on job satisfaction of executives in automobile companies in western province, Sri Lanka. Also findings reveal that existing level of performance management system is in high range in selected organizations.

\section{Conclusion of the Study}

It is concluded that performance management system has strong impact on employee job satisfaction of executives in automobile companies in western province, Sri Lanka.

Keywords: Performance Management System, Job Satisfaction, Executives, Automobile Companies

\section{Introduction}

No function is under greater review than the human resource function in this increasingly global competitive market (Bowker 1990) and performance management is one of the most important components of human resource management. Also, there is an emerging trend among organizations that shifting from employee performance appraisal system to performance management system (Yadav \& Dabhade 2013). Therefore, there can be seen significant attention to performance management system in Sri Lankan context also. Research on impact on performance management system on employee job satisfaction has become a research area of much importance in today's context. This study is an attempt to enhance the existing body of knowledge regarding the above mentioned area with a Sri Lankan approach. 
Performance management system maintains, develop and motivate the people who are at work in order to generate better results. Ultimately these better results cause to survive, stabilize, growth and excel of the organization which are very essential in present competitive business environment. In other words, a good performance management system helps to develop individual employees' abilities, enlarge job satisfaction and achieve their potential to their own advantages and also benefits to the Organization (Lawson 1995). Hence, it can be seen as critical factor to the development and survival of organizations as well as employees.

Employee job satisfaction can be considered as key to organizational success. It is essential to develop good employee job satisfaction in order to achieve the organizational goals and objectives. There are several factors which affecting employees' job satisfaction. According to the job satisfaction model developed by Field (2008), good leadership practices, good manager relationship, recognition of and advancement in the job, personal growth, feedback and support, and clear objectives can be considered as moderators to increase one's job satisfaction. Furthermore, Neog and Barura (2014) conducted the research in automobile workshops in Assam found that employees' job satisfaction of automobile industry mainly held with the compensation, training and development opportunities, career development and promotion, rewards and recognition, performance appraisal, supervisory support, autonomy and role clarity etc. Interesting fact is that almost all these factors are related to performance management system in the organization. Hence, it is very important to conduct the research in order to investigate the impact of performance management system on employee job satisfaction.

\section{Literature Review and Hypotheses Development}

There is significant number of research studies in the area of performance management system, but those are investigating the impact using different variable such as employee performance (Ying 2012). Also there can be found significant number of research studies which conducted for one part of the performance management system such as performance measurement (Rossi 2012; Degroff 2009). Furthermore, bulk of the researches was conducted in the area of job satisfaction (Zeffane 1994), and using with different factors such as absenteeism (Hackett \& Guion 1985; Hulin 1991), turnover (Carsten \& Spector 1987), and performance (Poasakoff \& Williams 1986). But there are limited research studies as Gupta and Upadhyay (2012), Gathoni (2012), Mallaiah (2008), Jaksic and Jaksic (2013) investigated the impact of performance management system on employee job satisfaction.

As well as those mentioned researches (Gupta \& Upadhyay 2012; Gathoni 2012; Mallaiah 2008; Jaksic \& Jaksic 2013) have been done worldwide using different variables but in Sri Lankan context researches which address the impact of performance management system to the employee job satisfaction states low. This research can be considered as an alternative to the scarcity. It is true that the situation is same in any industry, but this research is done to find out the impact of performance management system on employee job satisfaction with regards to the automobile companies in western province. 


\section{Performance Management System}

Performance Management (PM) represents a relatively new management concept. It was not until the 1980s that it actually emerged as a separate concept (McDonnell \& Gunnigle 2009). However, the first formal monitoring system was introduced by Frederick Taylor and his followers before 1st world war (Armstrong \& Baron 2010). According to the Armstrong and Baron (2010), it was introduced rating for US army officers in 1920 and then it spread to the UK also. Furthermore, performance appraisal was invented by W.D. Scott in early 1900's (Brooks 2015). But it was not a widely recognized concept in that time. At the mid 1950's formal performance appraisals were introduced and companies used personality based systems for measuring the performance (Brooks 2015). It was a personality based approach and therefore it was not much as useful for monitoring the performance. By the 1960's performance appraisals began to use by focusing more on goals and objectives (Brooks 2015). Hence it tent to introduce management by objectives (MBO) simultaneously with critical incident techniques and behaviourally anchored rating scales (BARS) (Armstrong \& Baron 2010). Performance management was developed from this management by objectives (MBO) approach. The next 20 years, there was more attention on employee motivation and engagement which led to a more holistic approach to the performance management and appraisals (Brooks 2015). In this time, a revised form of results- oriented performance appraisal emerged and still uses in nowadays (Armstrong \& Baron 2010). In recent years, performance management has evolved further and companies tend to use new methods and systems with mobile technology to manage the performance of employees (Brooks 2015).

In different literature, there are a variety of models for performance management and each model has its significance as a system for running organizational performance, employee performance, and integrating the management of organizational and employee performance (Ying 2012). Also performance management system can be considered as completed and integrated cycle for performance management (Ying 2012). Rudman (2003) defines performance management system as "means of integrating HRM activities with the business objectives of the organization, where management and HR activities are working together to influence individual and collective behavior to support the organization's strategy"(p. 238) Performance management systems are the formal, information-based routines and procedures that managers use to maintain or alter patterns in organizational activities (Simons 2000 cited in Hamumokola 2013). Also Ying (2012) mentioned that performance management involves multiple levels of analysis and is obviously linked to the topics studied in strategic HRM as well as performance appraisal.

After depth analysis of various organizations, it is found that every organization has been taken different steps and there is no similarity in steps in performance management process (Balyan 2011). Also various authors (Hartle 1994; Schneier et al. 1987 as cited in Ying 2012; Armstrong \& Baron 2010) identified different steps as the steps that included in performance management system. According to Hartle (1994), strategy and objectives, job definition, objective setting, coaching and counseling, performance review, skills training, performance related pay and training and development can be considered as the elements of performance 
management system. Furthermore, According to Schneier et al. (1987) as cited in Ying (2012), a performance management system consists with development, planning, managing, reviewing and rewarding phases. According to Chartered Institute of Personnel and Development (CIPD 2011), survey on current trends and practice of performance management, cornerstones of performance management system are performance appraisal, objective setting, regular feedback, regular reviews, performance related pay and assessment of development needs. Armstrong and Baron (2010) also identified that performance planning, defining expectations, objectives, measuring performance, reviewing performance, providing feedback, assessing performance, rating performance, coaching and documentation as the elements of performance management. Hence, there are no universally accepted phases or components in performance management system. According to previously mentioned different elements, components and phases of performance management system, researcher is supposed to use elements such as performance planning (goal setting and communication), managing performance (training, coaching and feedback), performance appraisal and rewarding performance as criteria's to measure the impact of the performance management system in this study.

\section{Job Satisfaction}

Job satisfaction is very important issues in organizational behavior (Chen at al 2012; Zeffane et al 2008) and management of human and material resources. Various authors and management scientists (Locke 1976 as cited in Ram 2013; Khan 2007; Hulin \& Judge 2003) define employee job satisfaction in many ways in their research studies, articles and books etc. One of the most well used definition of the job satisfaction is that Locke (1976) as cited in Ram (2013), define job satisfaction as “. . . a pleasurable or positive emotional state resulting from the appraisal of one's job or job experiences" (p. 08). Hence job satisfaction is an emotional state but it relates to the job of a person. Employee job satisfaction can be defined as the employee's satisfaction with the job and how well outcomes are in line with the one's personal expectation regarding his/her job (Khan 2007).

Job satisfaction can be considered as one of the important factor in determining efficiency and effectiveness of the organization. Because job satisfaction generates positive workplace outcomes such as increased organizational commitment, decrease propensity to leave etc. (Brown \& Peterson 1993). Job satisfaction is also important in reducing the absenteeism (Ostroff 1992; Spector 1997). On the other hand, high level of job satisfaction indicates that employees have good emotional and mental states. It directly impacts to their behaviours in the work place which is ultimately result in better functioning in the organizational activities in order to achieve organizational goals and objectives efficiently and effectively. On the other hand, a study published by the International Archives of Occupational and Environmental Health as cited in McFarlin (n.d.) found that workers who report low job satisfaction experienced several other issues at work such as job stress, poor overall morale, lack of productivity and high employee turnover rates as side effects. 
The Society of Human Resource Management (SHRM 2014) done a survey on job satisfaction and employee engagement using 600 U.S. employees and found out that employees are more satisfied with the criteria of compensation/pay, job security, career development opportunities, relationship with immediate supervisor, job specific training, level of autonomy and independence with current position and management recognition on employee performance. Employees are more satisfied with the criteria which directly or indirectly relating to the performance management system. Therefore performance management system plays a significant role in determining employee job satisfaction.

\section{Relationship between Performance Management System and Employee Job Satisfaction}

Gupta and Upadhyay (2012), did the research in top three private banks in Ahmedabad region and found that performance management system and job satisfaction are highly correlated with each other and there is significant impact of effectiveness of performance management system on employee satisfaction. Lawson (1995), stated that a good performance management system helps to develop individual employees' abilities, increase job satisfaction and achieve their potential to their own benefit and also benefits to the Organization. Armstrong (2000), mentioned that performance management is focused on satisfying the needs and expectations of organizations stakeholders most importantly including employees. On the other hand, Robby (2010) mentioned that practices relating to people, performance management and organization results have association with employees' satisfaction. Also Williams (1991) as cited in Gathoni (2012) ${ }^{[61]}$ and DDI (n.d.) as cited in Aguinis (2005) mentioned that if well implemented performance management system as planned will lead to employee satisfaction. Gathoni (2012) did the research in a NGO organization and concluded her research by stating that employee performance management practices enhance employee satisfaction. Torrington (2008), Fletcher and Williams (1996) also stressed that there is a positive relationship between performance management system and employee job satisfaction. Thus, based on these empirical evidences the first hypothesis of this study is developed as follows:

$\mathrm{H}_{1}$ : There is a positive relationship between performance management system and employee job satisfaction.

Well established performance planning leads to employee job satisfaction (Berger 2008 as cited in Gathoni 2012). Fletcher and Williams also (1996) mentioned that performance planning through goal-setting increases the job satisfaction. Decramer et al. (2012) did a research to investigate the relationship between performance management system and job satisfaction and found that the consistency of performance planning increased employee job satisfaction with the system. Thus, based on these empirical evidences the second hypothesis of this study is developed as follows:

$\mathrm{H}_{2}$ : Performance planning has a positive impact on employee job satisfaction.

Many authors include feedback, coaching, training as the activities of managing performance (Ying 2012) which is the second step of performance management system. According to Aguinis et al. (2011) effective performance feedback has a potentiality to enhance employee 
job satisfaction. Also performance feedback is an effective tool for enhancing employee job satisfaction (Islam \& Rasad 2006). On the other hand, training and development enhance the performance at the same time enhancing employee job satisfaction (Gathoni 2012; Gagne \& Deci 2005). Thus, feedback, coaching, training considered as the activities of managing performance and third hypothesis of this study are developed as follows:

$\mathrm{H}_{3}$ : Managing performance has a positive impact on employee job satisfaction.

With reference to the Herpen et al. (2005), Martinez (2005) job satisfaction is significantly positively affected by the fairness of the performance appraisal system. Waal (2003) found that performance appraisal improve employee job satisfaction. Ukko et al. (2008) did a research regarding the impact of performance measurement on the quality of life and found that there is a positive relationship between performance appraisal and the quality of working life including job satisfaction as a determinant among many other variable. Brown et al. (2010) found that low quality in performance appraisal (lowest levels of trust in supervisor, poor communication, lack of clarity about expectations, perception of a less fair PA process) results in lower level of job satisfaction. Thus, based on these empirical evidences the forth hypothesis of this study is developed as follows:

$\mathrm{H}_{4}$ : Performance appraisal has a positive impact on employee job satisfaction.

According to Usman and Danish (2010) rewarding system which link employee rewards to their performance leads to employee job satisfaction. Previous researchers (Heywood \& Wei 2006; Green \& Heywood 2008) also found that performance-related pay is associated with higher levels of job satisfaction. Furthermore, Bryson et al. (2012) investigated the relationship between piece-rate, team-incentive, or profit-sharing schemes and job satisfaction and found that employees who are under the performance related pay schemes are more satisfied with their job. Thus, based on these empirical evidences the fifth hypothesis of this study is developed as follows:

$\mathrm{H}_{5}$ : Rewarding performance has a positive impact on employee job satisfaction.

The relationship among the variables is clearly depicted in the theoretical framework which guides this current research to find out the possible relationship between the performance management system and employee job satisfaction. Figure 1 illustrates the conceptual framework of the study. 
Figure 1: Conceptual Framework of the Study

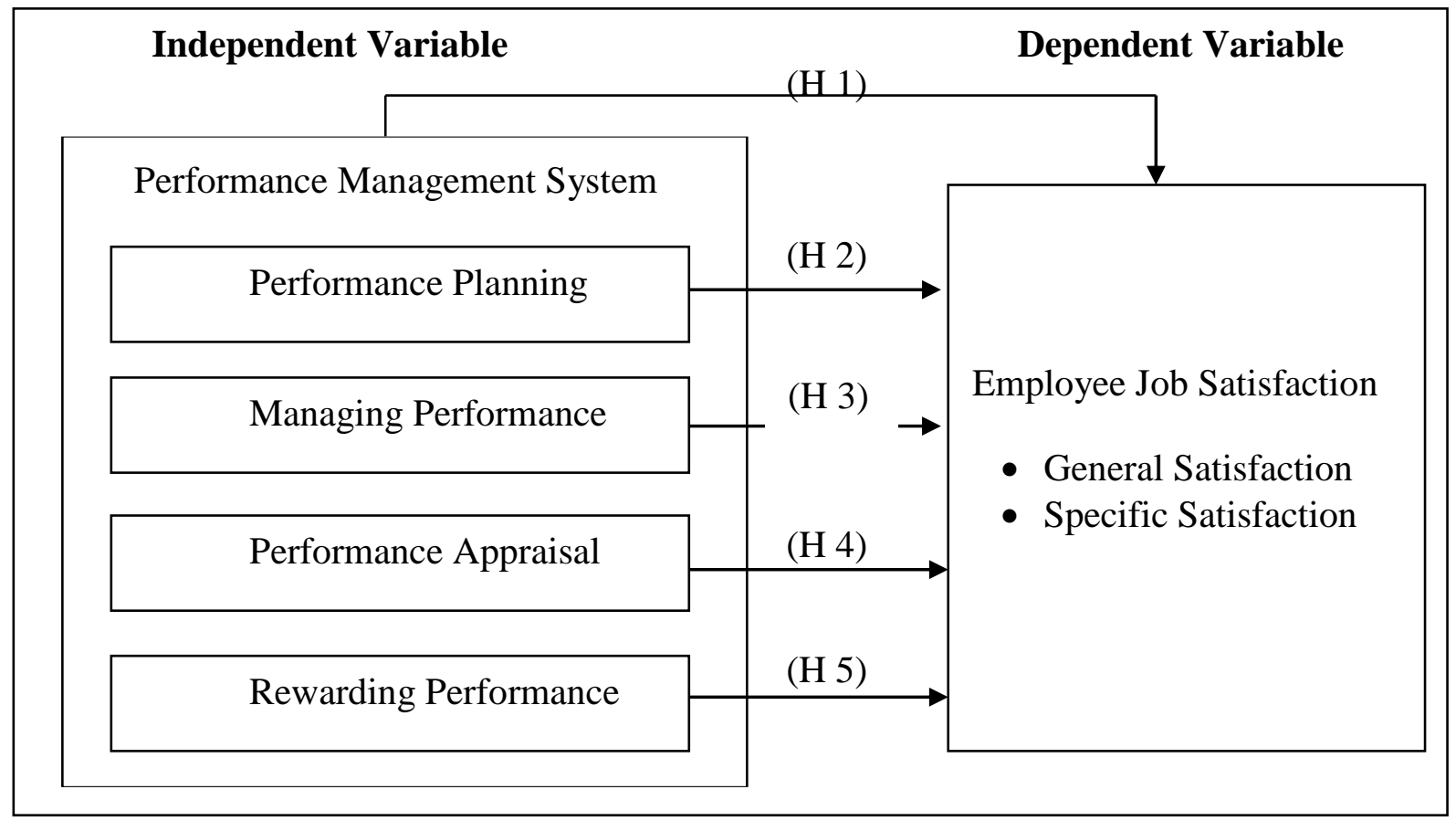

\section{Method}

\section{Sample and Data Collection}

The sample firms were selected from the 2013 to 2014 annual report of the Ceylon Motor Traders Association. Because of the time limitation, researcher supposed to use three selected automobile companies in western province and the target population was limited to all the executives and above level staff in automobile companies in western province. However, all the branches belong to these selected three organizations were considered excluding the rest of the branches beyond the western province. Because the population is very large, the researcher decided to select sample from the population. Convenience sampling method was employed to finalize the sample size of 248 respondents. Also, care was taken to ensure that the sample size is large enough to convey a measure of credibility to the outcome of the study.

Information was collected from a survey questionnaire which distributed to 248 executives and above level employees and the researcher gathered first hand data by distributing this questionnaire through hand delivery method. The response rate was 87 percent. Hence, researcher successfully collected 248 questionnaires all of which were effective and utilized these at each analysis stage. Among the respondents, 39.5 percent were aged 21- 30 years, 61.7 percent were married and most of the respondents were males.

\section{Scales and Variables}

The independent variable: performance management system and the dependent variable: job satisfaction was measured through questionnaire which was completed by the respondents themselves approximately as they have experienced. As prerequisites, researcher supposed to 
identify the extent to which those selected organizations adhere to performance management system. Thereby researcher was used a question as in Armstrong (2006) with the relevant modifications which directly questioning whether the features of performance management system is "available" or "not available". Also, the performance management system in automobile companies was measured in terms of four dimensions as performance planning (goal setting and communication), managing performance (training, coaching and feedback), performance appraisal and rewarding performance. The job satisfaction of executives and above level employees was measured with the questions which covering both general satisfaction and specific satisfaction. All the question statements in the instrument were developed in lined with the Armstrong (2006), Gathoni (2012), Maleka (2014) and Bekele et al. (2014). Five point Likert scale of 'strongly agree, agree, neutral, disagree and strongly disagree' were used in the questionnaire to measure both variables. The level of measurement of both variables would be interval and level of measurement for availability of the features of performance management system would be nominal. The questionnaire also consisted with six question items which questions relating to personal characteristics of the respondents.

\section{Measurement Validation}

The external reliability of the instruments used to collect data was examined by test - retest method and the inter item consistency reliability was examined by Cronbach's Alpha test. The results of the test - retest coefficient and Cronbach's Alpha test are given in the table 1, which suggests that the external and internal reliability of each instrument was at a satisfactory level (Kottawatta 2014).

Table 1: Results of Test - Retest and Cronbach's Alpha Test

\begin{tabular}{|l|c|c|}
\hline Instrument & Test - retest coefficient & Cronbach's Alpha \\
\hline Performance management system & 0.908 & 0.906 \\
\hline Job Satisfaction & 0.833 & 0.921 \\
\hline
\end{tabular}

The content validity of the instruments was ensured by the conceptualization and operationalization of the variables on literature and indirectly by the high internal consistency reliability of the instruments as denoted by Alphas.

Furthermore, the ceiling effect was calculated in order to find out any significantly strong correlation between the variables and results of these calculations are shown in table 2. It was attempt to ensure that the bi-variate association between these two variables was not greater than 0.7 (Hair et al 2006 as cited in Jayasekara \& Takahashi 2014). However, other than the dimensions of performance management system, correlations between two variables are less than 0.7 which are significant at 0.01 and 0.05 levels. Also, mean value of each variables are not more than 4.98 . These results indicate that there is no any ceiling effect. 
ISSN: $2012-7227$

HRM Scintilla 9

Human Resource Management Journal, 2017, Vol. 5, No. 1

\section{Techniques of Data Analyses}

Data collected from primary sources (questionnaire) were analyzed using the computer based statistical data analysis application, SPSS (version 16.0) for validity, reliability and relationship testing. The data analyses included univariate and bivariate analyses.

\section{Results}

As prerequisites, researcher supposed to identify the extent to which those selected organizations adhere to performance management system in the current organizational setting. In this regard, frequency analysis was conducted for each features of performance management system and continuum table was used for each four dimensions of performance management system. The results of the frequency distribution are given in Table 3 and Table 4.

Table 3: Frequency distributions for performance management system and job satisfaction

\begin{tabular}{|l|r|r|}
\hline Measure & \multicolumn{1}{|c|}{ PMS } & \multicolumn{1}{|c|}{ Job Satisfaction } \\
\hline Mean & 4.0810 & 4.1609 \\
\hline Median & 4.1250 & 4.3000 \\
\hline Mode & 4.12 & 4.50 \\
\hline Std. Deviation & .58880 & .62420 \\
\hline Variance & .347 & .390 \\
\hline Skewness & -.793 & -1.293 \\
\hline Std. Error of Skewness & .155 & .155 \\
\hline Kurtosis & 1.276 & 1.794 \\
\hline Std. Error of Kurtosis & .308 & .308 \\
\hline
\end{tabular}

The values for asymmetry and kurtosis between -2 and +2 are considered acceptable in order to prove normal univariate distribution (George \& Mallery 2010). As indicated by Table 3, data recorded for the performance management system and job satisfaction are normally distributed.

Table 4: Frequency analysis of features of performance management system

\begin{tabular}{|l|r|r|r|r|}
\hline \multirow{2}{*}{ Feature } & \multicolumn{2}{|c|}{ Availability } & \multicolumn{2}{c|}{ Non-availability } \\
\cline { 2 - 5 } & Frequency & \multicolumn{1}{|c|}{$\%$} & Frequency & \multicolumn{1}{|c|}{$\%$} \\
\hline Annual or twice- yearly (bi- annual) appraisal & 248 & 100 & - & - \\
\hline Subordinate feedback & 230 & 92.7 & 18 & 7.3 \\
\hline Objective setting & 241 & 97.2 & 27 & 2.8 \\
\hline Communicating the established targets & 240 & 96.8 & 8 & 3.2 \\
\hline Coaching and/or mentoring & 231 & 93 & 17 & 6.9 \\
\hline Sufficient training & 232 & 93.5 & 16 & 6.5 \\
\hline Performance related pay & 223 & 89.9 & 25 & 10.1 \\
\hline Career development & 225 & 90.7 & 23 & 9.3 \\
\hline
\end{tabular}


ISSN: 2012-7227

HRM Scintilla 10

Human Resource Management Journal, 2017, Vol. 5, No. 1

Table 5: Mean, SD and correlation among variables

\begin{tabular}{|c|c|c|c|c|c|c|c|c|c|c|c|c|c|c|}
\hline & Mean & SD & 1 & 2 & 3 & 4 & 5 & 6 & 7 & 8 & 9 & 10 & 11 & 12 \\
\hline Total job satisfaction & 4.1609 & .62420 & & & & & & & & & & & & \\
\hline PMS & 4.0810 & .58880 & $.840 * *$ & & & & & & & & & & & \\
\hline Performance planning & 4.2292 & .52770 & $.695 * *$ & $.811 * *$ & & & & & & & & & & \\
\hline Managing performance & 4.0641 & .65603 & $.798 * *$ & $.949 * *$ & $.721 * *$ & & & & & & & & & \\
\hline Performance appraisal & 3.9808 & .71827 & $.763 * *$ & $.898 * *$ & $.610 * *$ & $.800 * *$ & & & & & & & & \\
\hline Rewarding performance & 4.0151 & .76785 & $.706 * *$ & $.874 * *$ & $.570 * *$ & $.762 * *$ & $.811 * *$ & & & & & & & \\
\hline $\begin{array}{l}\text { Name of the } \\
\text { Organization }\end{array}$ & 2.3629 & .88014 & .075 & -.003 & -.010 & .049 & -.066 & -.025 & & & & & & \\
\hline Gender & 1.3024 & .46023 & .090 & .034 & $.119 *$ & .032 & -.010 & -.039 & .048 & & & & & \\
\hline Age & 2.9960 & .99999 & $.251 * *$ & $.200 * *$ & $.183^{* *}$ & $.173 * *$ & $.204 * *$ & $.175 * *$ & -.008 & $-173 * *$ & & & & \\
\hline Civil Status & 1.3831 & .48712 & $.277 * *$ & $.217 * *$ & $.193 * *$ & $-197 * *$ & $.225^{* *}$ & $.170 * *$ & -.052 & $.167 * *$ & $.612 * *$ & & & \\
\hline Exper.Current & 1.9073 & 1.13620 & $.141^{*}$ & .071 & .045 & .076 & .076 & .069 & .042 & $.163 * *$ & $.676^{* *}$ & $.521 * *$ & & \\
\hline Total work experience & 2.4593 & 1.20728 & $.276 * *$ & $.234 * *$ & $.189 * *$ & $.228 * *$ & $.226 * *$ & $.198 * *$ & .041 & $-184 * *$ & $.657 * *$ & $.673 * *$ & $.681 * *$ & \\
\hline Education & 4.1008 & .93185 & .099 & .083 & .008 & .096 & .101 & .071 & -.069 & -.052 & -.034 & -.041 & $.163 * *$ & -.051 \\
\hline
\end{tabular}

Notes: PMS, performance management system; Exper.Curretnt, Experience for the current organization. **. Correlation is significant at the 0.01 level (1-tailed), *. Correlation is significant at the 0.05 level (1-tailed). 
Section B of the questionnaire is devoted for mentioning the availability or non availability of the features of performance management system. The table 4 indicates the frequencies and percentage level of availability of each features of performance management system. According to this table, the percentages of availability of each features of performance management system were above than $85 \%$.

The results of continuum table of each dimensions of performance management system can be summarized as in Table 6.

Table 6: Summary result of continuum table for each dimensions of performance management system

\begin{tabular}{|l|l|l|l|}
\hline Dimension & Mean value & Standard Error & Range \\
\hline Performance Planning & 25.375 & 0.201 & High Range \\
\hline Managing Performance & 36.5766 & 0.3749 & High Range \\
\hline Performance Appraisal & 15.879 & 0.185 & High Range \\
\hline Rewarding Performance & 20.0685 & 0.238 & High Range \\
\hline
\end{tabular}

According to the table 6, all the dimensions of performance management system existed in high range. The highest mean value represents in the dimension of managing performance which is 36.5766 . The mean value of performance appraisal is 15.879 which is the lowest value compared to other dimensions. It is something common in practice in relation to the performance appraisal in Sri Lankan context.

The results of correlation analysis between performance management system and job satisfaction are summarized in table 07.

Table 07: The results of Pearson's Correlation between performance management system and job satisfaction

\begin{tabular}{|l|r|r|}
\hline & $\begin{array}{c}\text { Pearson } \\
\text { Correlation }\end{array}$ & Sig. (1-tailed) \\
\hline Performance planning and job satisfaction & .695 & 0.000 \\
\hline Managing performance and job satisfaction & .798 & 0.000 \\
\hline Performance appraisal and job satisfaction & .763 & 0.000 \\
\hline Rewarding performance and job satisfaction & .706 & 0.000 \\
\hline Performance management system and job satisfaction & .840 & 0.000 \\
\hline
\end{tabular}

Correlation coefficient between performance management system and job satisfaction of the sample respondents is .840 (sig: 0.000). It implies that there is a strong positive relationship between performance management system and job satisfaction. Furthermore, each dimension of performance management system, performance planning, managing performance, performance appraisal and rewarding performance are strong and positively correlated with job satisfaction and all are statistically significance. 
The results of simple regression analysis of the performance management system with job satisfaction are given in table 07.

Table 07: The results of simple regression analysis between performance management system and job satisfaction

\begin{tabular}{|l|l|l|l|l|l|}
\hline & PMS and JS & PP and JS & MP and JS & PA and JS & RP and JS \\
\hline R square & .705 & .483 & .637 & .582 & .499 \\
\hline Adjusted R Square & .704 & .481 & .636 & .580 & .497 \\
\hline $\mathrm{F}$ & 587.516 & 230.159 & 431.829 & 342.003 & 245.108 \\
\hline Significance & .000 & .000 & .000 & .000 & .000 \\
\hline$\beta$ - Constant & .529 & .683 & 1.074 & 1.5222 & 1.855 \\
\hline$\beta$ value & .840 & .695 & .798 & .763 & .706 \\
\hline
\end{tabular}

In reference to table 07 , regression coefficient $(\beta)$ of performance management system and job satisfaction is .840 (sig: 0.000 ), indicating that approximately $70.5 \%$ of the variance of the job satisfaction can be accounted for performance management system. Also, performance management system is significantly related to job satisfaction, where $\mathrm{F}$ value is 587.516. Furthermore, each dimension of performance management system, performance planning, managing performance, performance appraisal and rewarding performance are significantly related to job satisfaction.

All the results of correlation analysis and simple regression analysis for each hypotheses of this independent research study can be summarized as in table 08 .

Table 08: Summary results of each hypothesis testing

\begin{tabular}{|l|l|c|c|c|c|c|}
\hline \multirow{2}{*}{ Objectives } & \multirow{2}{*}{ Hypotheses } & \multicolumn{2}{|c|}{$\begin{array}{c}\text { correlation } \\
\text { coefficients }\end{array}$} & \multicolumn{2}{|c|}{$\begin{array}{c}\text { regression } \\
\text { coefficient }\end{array}$} & \multirow{2}{*}{$\begin{array}{c}\text { Accepted /Not accepted } \\
\text { Of the hypotheses }\end{array}$} \\
\cline { 3 - 6 } & & $\mathrm{r}$ & $\mathrm{p}$ & $\beta$ & $\mathrm{p}$ & \\
\hline Objective 1 & Hypothesis 1 & .840 & 0.000 & .840 & 0.000 & Accepted \\
\hline Objective 2 & Hypothesis 2 & .695 & 0.000 & .695 & 0.000 & Accepted \\
\hline Objective 3 & Hypothesis 3 & .798 & 0.000 & .798 & 0.000 & Accepted \\
\hline Objective 4 & Hypothesis 4 & .763 & 0.000 & .763 & 0.000 & Accepted \\
\hline Objective 5 & Hypothesis 5 & .706 & 0.000 & .706 & 0.000 & Accepted \\
\hline
\end{tabular}

As indicated in table 08, all the hypotheses are accepted according to the results of correlational and simple regression analyses. Also, all the objectives of this research study were achieved by testing the each hypothesis.

\section{Discussion and Conclusion}

The result of frequency analysis which conducted for each features of performance management system revealed that percentage of availability of each features of performance management system were above than $85 \%$. Also the results of continuum table used for each four dimensions of performance management system indicated that all four dimensions of 
performance management system were in "high range" in selected organizations. Hence, it was found that there is high availability of performance planning, managing performance, performance appraisal and rewarding performance in automobile companies in western province.

Also correlational and simple regression analysis of the sample data reveals that there is a strong positive relationship between performance planning and job satisfaction of executives and above level staff. Correlation coefficient between these two variables is 0.695 , which is significant at 0.000 level, $(\mathrm{p}=0.000)$. Results of simple regression analysis revealed that the strength of $\beta$ value is 0.695 which is significant at 0.000 level, $(p=0.000)$. Approximately $48.3 \%$ of the variance of the job satisfaction can be accounted for performance planning. This finding can be verified the findings of Berger (2008) as cited in Gathoni (2012), Fletcher and Williams (1996) and Decramer et al. (2012). Hence the hypothesis two is accepted.

As the findings of the study, there is a strong positive relationship between managing performance and job satisfaction of executives and above level staff. The correlation between these variables was 0.798 , which is significant at 0.000 level, $(p=0.000)$. Further simple regression analysis revealed that $63.7 \%$ of the variance of the job satisfaction can be accounted for managing performance. This study findings confirmed by the studies done by Aguinis et al (2011), Islam and Rasad (2006), Gathoni (2012), Gagne and Deci (2005) and Ying (2012) relating to the each activities of managing performance such as training, coaching, feedback. Hence the hypothesis three is accepted.

Performance appraisal and job satisfaction of executives and above level staff is recorded also as strong positive relationship. Correlation coefficient between these two variables is 0.763 and regression coefficient is 0.763 , both are significant at 0.000 level, $(p=0.000)$. Also, $58.2 \%$ of the variance of the job satisfaction can be accounted for performance appraisal. Herpen et al. (2005) ${ }^{[}$, Martinez (2005), Waal (2003), Ukko et al. (2008) also pointed out the positive relationship between these two variables. Hence the hypothesis four is accepted.

Findings further shows that there is a positive relationship between rewarding performance and job satisfaction of executives and above level staff. The correlation between these variables was 0.706 , which is significant at 0.000 level $(p=0.000)$. Approximately $49.9 \%$ of the variance of the job satisfaction can be accounted for rewarding performance. Findings of current study relating to rewarding performance also similar to the findings obtained by Usman and Danish (2010), Heywood and Wei (2006) and Green and Heywood (2008). Hence, Hypothesis 5 is accepted.

The results of this study also reveal that there is a positive relationship between performance management system and job satisfaction of executives and above level staff. The correlation between these variables was 0.840 , which is significant at 0.000 level, $(p=0.000)$. The 
results of simple regression analysis reveal that the strength of $\beta$ value is 0.840 which is significant at 0.000 level, $(\mathrm{p}=0.000)$. Approximately $70.5 \%$ of the variance of the job satisfaction can be accounted for performance management system. According to the results of simple regression analysis, regression equation of performance management system is: Job satisfaction $=0.529+0.890$ (Performance management system). There is a consistency of the findings of the study with the findings of the researches conducted by Gupta and Upadhyay (2012), Lawson (1995), Armstrong (2000), Robby (2010), Gathoni (2012), Aguinis (2005), Torrington (2008), Fletcher and Williams (1996). Hence, hypothesis 1 is accepted.

As a conclusion, the research findings revealed that there was a strong positive impact of independent variable (performance management system) for the dependent variable (job satisfaction) in executives and above level staff in automobile companies in western province. In fact variation that occur in existing performance management system in automobile companies significantly affect to the job satisfaction of executives and above level staff in the selected organizations. Also the findings of this research study shall be important on the theoretical as well as practical scenario. These findings are important to improve job satisfaction of the executives and above level staff in automobile companies in western province.

In the light of the findings of this study, researcher supposed to provide several managerial implications and recommendations for further researchers who interested in same filed. Automobile companies in western province should pay their much attention to maintain the status quo of performance management system. As a major way of maintaining the existing level of job satisfaction of executives and above level staff in automobile companies, programs that currently conducting for performance planning (goal setting and communicating the established goals), managing performance (training, coaching, feedback), performance appraisal and rewarding performance need to be conducted in successfully. As well as organizations need to invest more time for maintain sound performance planning, managing performance, performance appraisal and rewarding performance throughout the year. Further researches are recommended for conducting beyond the western province and targeting the all employees for validating and generalizing the findings. Also it is recommended to expand to other industries in Sri Lankan context. Also this research did not consider about the impact of demographic variables owing to the existing male biasness in automobile industry. Therefore, further researches are recommended to conduct in investigating the impact of demographic variables. It is recommended to investigate the same impact by using the contemporary dimensions of performance management system. As well as further research studies are suggested to carry out testing the mediating impact of many other variables influencing the effectiveness of performance management system. 


\section{References}

i. Aguinis, H 2005, Performance management, Heriot- Watt University, Great Britain, Edinburgh.

ii. Armstrong, M \& Baron, A 2010, Performance management and development, Jaico, Mumbai.

iii. Armstrong, M 2000, Performance management: key strategies and practical guidelines, Kogan Page, London.

iv. Balyan, VS 2011, Analytical study of labour productivity and its impact on banking sector, Saurashtra University.

v. Bekele, AZ, Shigutu, AD \& Tensay, AT 2014, 'The effect of employees' perception of performance appraisal on their work outcomes', International Journal of Management and Commerce Innovations, vol. 2, no. 1, pp. 136 - 173.

vi. $\quad$ Bowker, 1990, Ulrich's international periodicals directory, New York.

vii. Brooks, S 2015, A brief history of performance management, viewed 25 October 2015, $\quad$ http://www.peoplehr.com/blog/index.php/2015/03/25/a-brief-history-ofperformance-management/

viii. Brown, M, Hyatt, D \& Benson, J 2010, 'Consequences of the performance appraisal experience’, Personnel Review, vol. 39, no. 3, pp. 375-396.

ix. Brown, SP \& Peterson, RA 1993, 'Antecedents and consequences of salesperson job satisfaction: meta-analysis and assessment of causal effects', Journal of Marketing Research, vol. 30, pp. 63-77.

x. Bryson, A, Clark, AE \& Freeman, RB 2012, Does how you are paid affects the way you feel? Mimeo.

xi. Carsten, JM \& Spector, PE 1987, 'Unemployment, job satisfaction, and employee turnover: a meta-analytic test of the muchinsky model', Journal of Applied Psychology, vol. 72, pp. 374-81.

xii. Chartered Institute of Personnel and Development 2011, performance management in action: current trends and practices, Online Survey report, CIPD, London, viewed 19 september 2015, http:// www.cipd.co.uk.

xiii. Chen, XH, Zhao, K, Liu, X \& Wu, DD 2012, 'improving employees' job satisfaction and innovation performance using conflict management', International Journal of Conflict Management, vol. 23, no. 2 pp. $151-172$.

xiv. Decramer, A, Smolders, C, \& Vanderstraeten, A 2012, 'Employee performance management culture and system features in higher education: relationship with employee performance management satisfaction', The International Journal of Human Resource Management, vol. 24, no. 2, pp. 352-371.

xv. DeGroff, AS 2009, New public management and governance collide: federal-level performance measurement in networked public management environments, Georgia Institute of Technology \& Georgia State University.

xvi. Field, J 2008, Model of job satisfaction, http://talentedapps.wordpress.com/2008/04/11/job-satisfaction-model-for-retention/. 
xvii. Fletcher, C \& Williams, R 1996, 'Performance management, job satisfaction and organizational commitment', British Journal of Management, vol.7, no. 2, pp. 169179.

xviii. Gagne, M \& Deci, EL 2005, 'Self-determination theory and work motivation', Journal of Organizational Behavior, vol. 26.

xix. Gathoni, NL 2012, Perceived effect of performance management practices on employee satisfaction at Swedish Cooperative Centre, Nairobi.

xx. George, D \& Mallery, P 2003, SPSS for Windows step by step: A simple guide and reference, 4th edn, Allyn \& Bacon, Boston.

xxi. Green, C \& Heywood, JS 2008, 'Does performance pay increase job satisfaction?', Economica, vol. 75, no. 300, pp. 710-728.

xxii. Gupta, A \& Upadhyay, D 2012, 'Impact of effectiveness of performance management system on employee satisfaction and commitment', International Journal of Management, IT and Engineering, vol. 2, no. 7.

xxiii. Hackett, RD \& Guion, RM 1985, 'A reevaluation of the absenteeism-job satisfaction relationship', Organizational Behavior and Human Decision Processes, vol. 35, pp. 340-81.

xxiv. Hamumokola, NN 2013, The contributions of performance management systems to performance in the namibian context, Johannesburg in handbook of policing, Willan Publishing Ltd, South Africa.

xxv. Hartle, F 1994, 'Performance management-where is it going?', in Mitrani, A and Dalziel, M (eds), Competency Based Human Resource Management: Value- Driven Strategies for Recruitment, Development and Reward, Kogan Page, Euro Business Publishing Network, France.

xxvi. Herpen, M, Praag, M, Cools, K 2005, 'The effects of performance measurement and compensation on motivation: an empirical study', The economist, vol. 153, pp. 303329.

xxvii. Herpen, M, Praag, M, Cools, K 2005, 'The effects of performance measurement and compensation on motivation: an empirical study', The economist, vol. 153, pp. 303329.

xxviii. Heywood, J S \& Wei, X 2006, 'Performance pay and job satisfaction', Journal of Industrial Relations, vol. 48, no. 4, pp. 523-540.

xxix. Heywood, J S \& Wei, X 2006, 'Performance pay and job satisfaction', Journal of Industrial Relations, vol. 48, no. 4, pp. 523-540.

xxx. Hulin, CL 1991, 'Adaptation, commitment, and persistence in organizations', in Dunnette, MD \& Hough, LM (eds), Handbook of Industrial and Organizational Psychology, vol. 2, Consulting Psychologists Press, Palo Alto, CA.

xxxi. Islam, R \& Rasad, SM 2006, 'Employee performance evaluation by the AHP', Asia Pacific Management Review, pp. 163-176.

xxxii. Jaksic, M \& Jaksic, M 2013, Performance management and employee satisfaction.

xxxiii. Jaksic, M \& Jaksic, M 2013, Performance management and employee satisfaction.

xxxiv. Jayasekara, P \& Takahashi, Y 2014, 'Improving post-assignment behavioral outcomes of expatriates', Journal of Global Mobility, vol. 2, no. 3, pp. 298-316. 
xxxv. Khan, A 2007, 'Performance appraisals relation with productivity and job satisfaction', Journal of Managerial Sciences.

xxxvi. Kottawatta, HK 2014, Research guide book, Department of Human Resource Management, University of Sri Jayewardenepura, Nugegoda.

xxxvii. Lawson, P 1995, 'Performance management: an overview', The Performance Management Handbook, IPD, London.

xxxviii. Lawson, P 1995, 'Performance management: an overview', The Performance Management Handbook, IPD, London.

xxxix. Maleka, S 2014, Critical assessment of the effectiveness of performance management system of the department of communications, viewed 19 october 2015, http://www.researchgate.net/publication/272688522

xl. Mallaiah, TY 2008, 'performance management and job satisfaction of university library professionals in Karnataka: A study', Journal of Library and IT, vol. 28, no.6, pp. 39-44.

xli. Martinez V 2005, What is the value of using performance management systems? centre for business performance, Cranfield School of Management, UK.

xlii. Martinez V 2005, What is the value of using performance management systems? centre for business performance, Cranfield School of Management, UK.

xliii. McDonnell, A \& Gunnigle, P 2009, 'Performance Management', in Collings, DG \& Wood, G (eds.) Human Resource Management: A Critical Approach.

xliv. Mcfarlin, K n.d., The effects of low job satisfaction, viewed 15 October 2015, http://smallbusiness.chron.com/effects-low-job-satisfaction-10721.html

xlv. Neog, BB \& Barua, M 2014, 'Factors influencing employee's job satisfaction: an empirical study among employees of automobile service workshops in Assam', The SIJ Transactions on Industrial, Financial \& Business Management (IFBM), vol. 2, no. 7.

xlvi. Ostroff, C 1992, 'The relationship between satisfaction, attitudes, and performance: an organizational level analysis', Journal of Applied Psychology, vol. 77, pp. 963-74.

xlvii. Podsakoff, PM \& Williams, LJ 1986, 'The relationship between job performance and job satisfaction', in Locke, EA (ed.), Generalizing from Laboratory to Field.

xlviii. Ram, P 2013, 'Relationship between job satisfaction and job performance in the public sector - a case study from India', International Journal of Academic Research in Economics and Management Sciences, vol. 2, no. 2.

xlix. Robby, OW 2010, Performance Management and Employee satisfaction in Insurance Company of East Africa Kisumu Branch, University of Nairobi.

1. Rossi, AC 2012, Proposal of a performance measurement system for e-commerce SMEs in Denmark, Aarhus University.

li. Rudman, R 2003, Human resource management in New Zealand, Pearson Education, Auckland.

lii. Society for Human Resource Management 2014, Survey on job satisfaction and employee engagement, SHRM, USA.

liii. Spector, PE 1997, Job satisfaction, Sage, Thousand oaks, CA. 
liv. The Ceylon Motor Traders' Association 2014, Annual report of Ceylon motor traders association $\quad-2013 / 2014, \quad$ viewed $17 \quad$ November 2015, http://www.cmtalanka.com/downloads/cmta-annualreport-2013-2014.pdf

lv. Torrington, D 2008, Human resources management, 6th edn, Pearson Education. England.

lvi. Ukko, J, Tenhunen, J \& Rantanen, H 2008, 'The impact of performance measurement on the quality of working life', International Journal of Business Performance Management, vol. 10, pp. 86-98.

lvii. Usman, A \& Danish, RQ 2010, 'Impact of reward and recognition on job satisfaction and motivation: an empirical study from Pakistan', International Journal of Business management, vol. 16, pp. 83-94.

lviii. Usman, A \& Danish, RQ 2010, 'Impact of reward and recognition on job satisfaction and motivation: an empirical study from Pakistan', International Journal of Business management, vol. 16, pp. 83-94.

lix. Waal, de AA 2003, 'Behavioural factors important for the successful implementation and use of performance management systems', Management decisions, vol. 41, no. 8, pp. 688-697.

1x. Yadav, RK \& Dabhade, N 2013, 'Performance management system in Maharatna Companies (a leading public sector undertaking) of India - a case study of B.H.E.L., Bhopal (M.P.)', Letters of Social and Humanistic Sciences, vol. 4 , pp. 49-69.

1xi. Ying, ZY 2012, The impact of performance management system on employee performance, analysis with WERS 2004.

lxii. Zeffane, R 1994, 'Correlates of job satisfaction and their implications for work redesign', Public Personnel Management, vol. 23, pp. 61-75.

1xiii. Zeffane, R, Ibrahim, ME, Mehairi, RA 2008, 'Exploring the differential impact of job satisfaction on employee attendance and conduct', Employee Relations, vol.30, no. 3, pp. 237- 250 .

\begin{tabular}{ll}
\hline Sandalika, KDM & $\begin{array}{l}\text { Department of Human Resource Management } \\
\text { University of Sri Jayewardenepura } \\
\text { jhrm@ @jp.ac.lk }\end{array}$ \\
\hline Jayasekara, P & Senior Lecturer \\
& $\begin{array}{l}\text { Department of Human Resource Management } \\
\text { University of Sri Jayewardenepura } \\
\text { padmijk@ sjp.ac.lk } \\
\text { jhrm@sjp.ac.lk }\end{array}$ \\
\hline
\end{tabular}

